\title{
Sistem Pendukung Keputusan Penilaian Widyaiswara Pendidikan dan Pelatihan CPNS Menggunakan Metode TOPSIS Pada BPSDM Sulawesi Tenggara
}

\author{
La Ode Bakrim ${ }^{1}$, Aris Susanto ${ }^{2}$, Omar Wahid $^{3}$ \\ vbakrim@gmail.com \\ ${ }^{1,2}$ STIMIK Bina Bangsa Kendari \\ ${ }^{3}$ AMIK Yapenas Kendari
}

\begin{abstract}
Abstrak
Penelitian ini bertujuan untuk mengembangkan sistem pendukung keputusan yang dapat mengevaluasi widyaiswara pelatihan CPNS pada BPSDM Provinsi Sulawesi Tenggara. Metode pengumpulan data yang digunakan dalam penelitian ini yaitu studi literatur, observasi, dan kuisioner. Sedangkan metode analisis data yang digunakan yaitu algoritma TOPSIS dengan merangking setiap widyaiswara berdasarkan nilai preferensi yang diperoleh. Hasil pengujian akurasi metode TOPSIS dalam penelitian ini sangat rendah. Namun, berdasarkan alternatif keputusan yang direkomendasikan TOPSIS memiliki kesesuaian dengan alternatif yang direkomendasikan secara konvensional.
\end{abstract}

Kata kunci: Sistem Pendukung Keputusan, Widyaiswara, TOPSIS

\section{Abstract}

This study aims to develop a decision support system that can evaluate CPNS training widyaiswara at BPSDM Southeast Sulawesi Province. Data collection methods used in this research are literature study, observation, and questionnaires. While the data analysis method used is the TOPSIS algorithm by ranking each widyaiswara based on the preference value obtained. The results of testing the accuracy of the TOPSIS method in this study are very low. However, based on the recommended decision alternatives, TOPSIS has conformity with conventionally recommended alternatives.

Keywords: Decision Support System, Widyaiswara, TOPSIS

\section{Pendahuluan}

Pemanfaatan Teknologi Informasi dalam kehidupan sehari-hari sangatlah membantu dan mempermudah pekerjaan manusia terutama dalam lingkup perkantoran, bukan hanya terbatas pada surat menyurat melainkan dapat digunakan dalam berbagai hal termasuk sebagai penunjang dalam pengambilan keputusan oleh pimpinan. Selain itu, digunakan untuk meningkatkan kinerja sistem yang ada didalam organisasi termasuk dibidang pendidikan dan pelatihan. Salah satu organisasi pemerintah yang menyelenggarakan pendidikan dan pelatihan adalah Badan Pengembangan Sumber Daya Manusia (BPSDM) Provinsi Sulawesi Tenggara.Fungsi lembaga ini berperan dalam pengembangan kompetensi dan sertifikasi sumber daya manusia dan memiliki misi salah satunya adalah meningkatkan kualitas tenaga kepelatihandemi terwujudnya sumber daya aparatur yang professional.

Upaya yang dilakukan lembaga tersebut untuk meningkatkan kualitas tenaga kepelatihan yaitu dengan melakukan evaluasi pada setiap pelatihan. Hal ini, dilakukan berdasarkan Peraturan Lembaga Administrasi Negara (LAN) Nomor 12 Tahun 2018 pasal 17 menyatakan evaluasi pelatihan dasar CPNS terdiri dari evaluasi peserta, evaluasi tenaga pelatihan, dan evaluasi penyelenggaraan [1].

Proses evaluasi yang dilakukan terhadap setiap komponen widyaiswara yang sedang berjalan pada lembaga tersebut disetiap pelatihan yaitu dilakukan dengan membagikan kuisioner melalui link dalam bentuk google form yang selanjutnya di isi oleh setiap peserta.Namun, metode tersebut kurang efektif dikarenakan penilaian yang diberikan responden masih perlu diolah lebih lanjut untuk mendapatkan hasil evaluasi rangking dari setiap tenaga pelatihan. 
Jurnal Sistem Informasi dan Sistem Komputer, Vol. 5, No. 1, Januari 2020

pISSN : 2581-1614 eISSN : 2715-906X

Hasil pengamatan yang dilakukan berdasarkan permasalahan tesebut, maka untuk memudahkan proses evaluasi diperlukan alat bantuyang tepat yang dapat digunakan untuk mengevaluasi kualitas tenaga pelatihan berdasarkan penilaian peserta pelatihan. Sehingga mendapatkan hasil penilaian yang logis, rasional dan terstruktur.Oleh karena itu, disarankan menggunakan sistem pendukung keputusan untuk mempermudah dan mempercepat pimpinan dalam pengambilan keputusan.

Ada beberapa penelitian sebelumnya yang sudah dilakukan oleh beberapa peneliti dengan menggunakan metode untuk sistem pengambilan keputusan diantaranya penelitian Muhamad Meky Frindo yaitu mengevaluasi kinerja karyawan menggunakan metode SAW [2]. Penelitian Achmad Azhar Azhari, dkk tentang perbandingan metode SAW dan TOPSIS pada penerimaan siswa praktek kerja lapangan [3]. Selanjutnya penelitian yang dilakukan oleh Wina dan Rahayu yaitu menganalisa perbandingan metode TOPSIS, SAW dan WP melalui uji sensitifitas supplier terbaik [4]. Penelitian Sukerti tentang penerapan Fuzzy TOPSIS untuk seleksi penerima bantuan kemiskinan [5].

Mencermati beberapa penelitian terdahulu, umumnya peneliti menggunakan pendekatan kualitatif dalam mengumpulkan data atau informasi. Pendekatan ini cukup baik tetapi lemah pada background responden dan akurasi dalam menjawab pertanyaan. Perbedaan lainnya dengan penelitian yang dilakukan penulis terletak pada variablel input atau kriteria serta metode yang digunakan.

Peneliti menyimpulkan bahwa metode TOPSIS dapat digunakan dalam penelitian ini karena studi kasusnya hampir sama hanya berbeda pada kriteria yang digunakan. Beberapa penelitian terdahulu menyarankan menggunakan metode tersebut karena prosesnya lebih cepat dibandingkan metode lain seperti SAW dan WP. Selain itu, metode tersebut cukup mudah untuk dipahami.

Sebagai upaya untuk memudahkan evaluasi widyaiswara pelatihan CPNS pada lembaga tersebut digunakan Sistem Pendukung Keputusan Perangkingan Widyaiswara dengan menggunakan metode Technique for Order of Preference by Similarity to Ideal Solution untuk mengevaluasi dan mengukur kualitas coach, pengampu materi, penceramah, mentor, dan penguji.

\section{Landasan Teori}

\subsection{Definisi Sistem Pendukung Keputusan}

Sistem pendukung keputusan dibuat untuk mendukung solusi atas suatu masalah. Aplikasi sistem pendukung keputusan digunakan sebagai dasar pengambilan keputusan untuk mendukung solusi atas masalah manajemen spesifik yang tidak terstruktur.

Menurut Ditdit Nugeraha sistem pendukung keputusan dibutuhkan untuk mendukung solusi sebuah permasalahan yang memiliki kompleksitas yang tinggi dalam rangka mengambil keputusankeputusan besar yang memiliki resiko sangat besar jika keputusan itu salah pilih dan dibutuhkan analisis dan perlengkapan data serta informasi yang mumpuni [6].

Menurut Turban, sistem pendukung keputusan merupakan sistem informasi yang berbasis komputer yang fleksibel, interaktif dan dapat diadaptasi, yang dikembangkan untuk mendukung solusi untuk masalah manajemen spesifik yang tidak terstruktur. Sistem pendukung keputusan menggunakan data, memberikan antarmuka pengguna yang mudah dan dapat menggabungkan pemikiran pengambilan keputusan [7].

Menurut Kusrini, sistem penunjang keputusan biasanya dibangun untuk mendukung solusi atas suatu masalah untuk mengevaluasi suatu peluang. Aplikasi sistem pendukung keputusan menggunakan CBIS (Computer Based Information System) yang fleksibel, interaktif, dan dapat diadaptasi, yang dikembangkan untuk mendukung solusi atas permasalahan manajemen spesifik yang tidak terstruktur [8].

\subsection{TOPSIS (Technique for Order Of Preference by Similarity to Ideal Solution)}

Metode TOPSIS adalah salah satu metode pengambilan keputusan yang optimal untuk menyelesaikan masalah keputusan secara praktis [9]. Metode ini dapat digunakan untuk pengambilan keputusan multi kriteria atau alternatif pilihan yang merupakan alternatif yang mempunyai jarak terkecil 
Jurnal Sistem Informasi dan Sistem Komputer, Vol. 5, No. 1, Januari 2020

pISSN : 2581-1614 eISSN : 2715-906X

dari solusi ideal positif dan jarak terbesar dari solusi ideal negatif dari sudut pandang geometris dengan menggunakan jarak Euclidean [10]. Secara umum, langkah-langkah prosedur metode TOPSISyaitu:

1. Menentukan matriks keputusan yang ternormalisasi;

2. Menghitung matriks keputusan ternormalisasi yang terbobot;

3. Menghitung matriks solusi ideal positif dan matriks solusi ideal negatif;

4. Menghitung jarak antara nilai setiap alternatif dengan matriks solusi ideal positif dan matriks solusi ideal negatif;

5. Menghitung nilai preferensi untuk setiap alternatif.

\subsection{Pendidikan dan Pelatihan}

Berdasarkan Peraturan Pemerintah Republik Indonesia Nomor 101 Tahun 2000 tentang Pendidikan dan Pelatihan Jabatan PNS, Pendidikan dan Pelatihan adalah proses penyelenggaraan belajar mengajar dalam rangka meningkatkan kemampuan Pegawai Negeri Sipil [11]. Menurut Notoadmodjo pendidikan dan pelatihan adalah upaya mengembangkan sumber daya manusia yaitu kemampuan intelektual dan kepribadian manusia [12]. Sedangkan menurut Subagio, pendidikan dan pelatihan adalah aktifitas yang meliputi usaha memberikan pengetahuan dan keterampilan kepada para pegawai dengan maksud agar pelaksanaan diklat lebih efektif [13]

\subsection{Widyaiswara}

Widyaiswara adalah Pegawai Negeri Sipil yang diangkat sebagai pejabat fungsional dengan tugas, tanggung jawab, wewenang, dan hak untuk melakukan kegiatan proses belajar dalam Diklat Pegawai Negeri Sipil, Evaluasi dan Pengembangan Diklat pada Lembaga Diklat Pemerintah [14].

\subsection{Evaluasi}

Widyaiswara adalah Pegawai Negeri Sipil yang diangkat sebagai pejabat fungsional dengan tugas, tanggung jawab, wewenang, dan hak untuk melakukan kegiatan proses belajar dalam Diklat Pegawai Negeri Sipil, Evaluasi dan

Setiap pelaksanaan pendidikan dan pelatihan selalu diikuti dengan evaluasi untuk melihat hasil proses pendidikan dan pelatihan yang dilakukan. Menurut Groundlund evaluasi adalah proses yang sistematis dalam pengumpulan data, analisis data dan interpretasi informasi untuk menentukan tingkat pencapaian tujuan pengajaran [15]. Sedangkan Djaali dan Mulyono menyatakan bahwa evaluasi sebagai proses menilai sesuatu berdasarkan kriteria atau tujuan yang telah ditetapkan, kemudian diambil keputusan atas obyek yang di evaluasi [16].

Selanjutnya menurut Blaine dan Sander, evaluasi adalah mencari sesuatu yang berharga (worth). Sesuatu yang berharga tersebut, dapat berupa informasi tentang suatu program, produksi serta alternatif prosedur tertentu [17]. Sedangkan menurut Kaufman dan Thomas menyatakan bahwa evaluasi adalah suatu proses yang dilakukan untuk membantu seseorang atau alat tertentu menjadi lebih baik dari keadaan yang sebelumnya karena adanya sistem perbaikan [18].

\section{Metode}

\subsection{Metode Pengumpulan Data}

Metode pengumpulan data yang digunakan pada penelitian ini adalah metode studi literatur, observasi, dan kuisioner.

1. Studi Literatur

Metode studi literatur merupakan salah satu metode pengumpulan data yang dilakukan dengan cara membaca referensi berupa buku atau jurnal penelitian sesuai dengan data yang dibutuhkan.

2. Observasi 
Metode observasi merupakan suatu metode pengumpulan data dengan mengadakan pengamatan secara langsung, cermat dan sistematis atas fenomena yang sedang diteliti. Dari hasil observasi diperoleh data-data yang berkaitan dengan penelitian yang akan dilakukan seperti mengetahui jumlah peserta yang dianggarkan selama satu tahun.

3. Kuisioner

Kuisioner merupakan susunan daftar pertanyaan yang diisi oleh responden. Hasil pengisian kuisioner harus dapat memberikan informasi suatu keadaan, pengalaman, pengetahuan sikap, atau pendapat dari responden. Kuisioner berisi pertanyaan atau pernyataan dengan cara memberikan jawaban penilaian berupa nilai interval $0-100$ pada kriteria penilaian yang sudah disediakan.

\subsection{Tahapan Penelitian}

Tahapan penelitian dibuat untuk memudahkan membaca penelitian yang dilaksanakan.Tahapan penelitian ini dirangkai dalam bentuk diagram alir yang ditunjukkan pada Gambar 1.

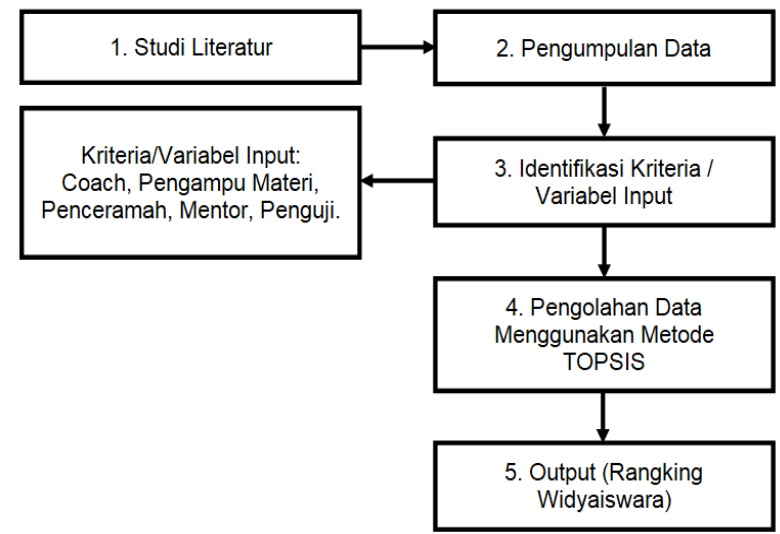

Gambar 1. Tahapan Penelitian

\section{Hasil dan Pembahasan}

\subsection{Analisa Kebutuhan Sistem}

Badan Pengembangan Sumber Daya Manusia Provinsi Sulawesi Tenggara sudah memiliki sistem informasi manajemen diklat dimana salah satu fungsinya dapat merekap hasil evaluasi peserta terhadap coach, pengampu materi, penceramah, mentor, dan penguji. Akan tetapi, selama ini belum memiliki sistem yang dapat membantu menganalisis hasil evaluasi yang dapat menggambarkan tingkat kepuasan peserta terhadap pelaksanaan diklat. Oleh karena itu, lembaga tersebut mengalami kendala untuk menggambarkan kualitas pelaksanaan diklat dan menentukan skala prioritas peningkatan kualitas diklat dimasa yang akan datang. Untuk mengetahui skala prioritas peningkatan layanan diklat sebaiknya lembaga tersebut memiliki sistem yang dapat membantu mengevaluasi pelaksanaan diklat. Pembangunan aplikasi untuk mengevaluasi pelaksanaan diklat memiliki fitur antara lain input penilaian responden, menampilkan penilaian responden, analisis hasil penilaian responden dengan metode TOPSIS, dan menampilkan hasil analisis dari metode TOPSIS..

\subsection{Perancangan Sistem}

Perancangan sistem merupakan penggambaran fungsionalitas dari suatu sistem. Berikut rancangan sistem yang digambarkan dalam bentuk Use Case Diagram pada Gambar 2. 


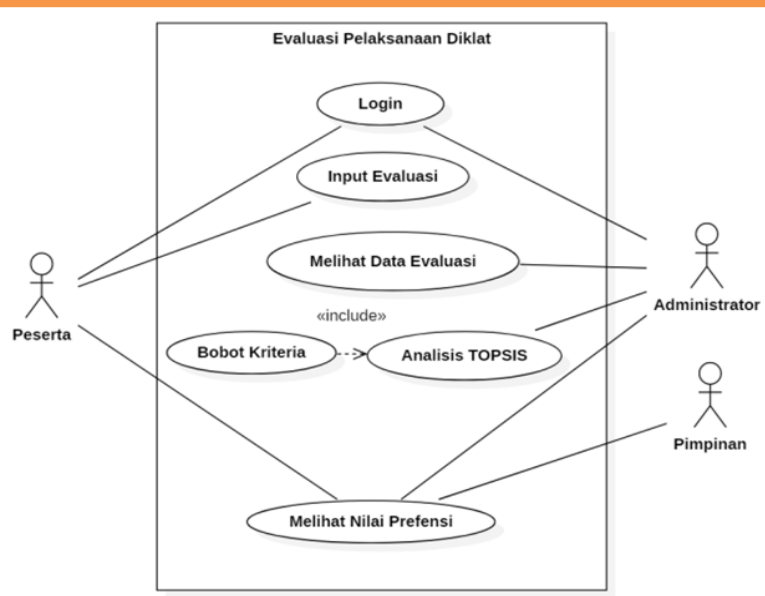

Gambar 2. Use Case Diagram

\subsection{Deskripsi Data}

Data yang diolah dalam penelitian ini bersumber dari kuisioner yang telah diisi oleh peserta pendidikan dan pelatihan dasar CPNS golongan II dan golongan III melalui aplikasi SIMDIKLAT. Adapun peserta yang mengikuti pendidikan dan pelatihan yaitu CPNS golongan II dengan jumlah peserta 160 orang yang terdiri dari angkatan VIII 40 orang, angkatan IX 40 orang, angkatan X 40 orang, angkatan XI 40 orang. Sedangkan untuk CPNS golongan III jumlah peserta 156 orang yang terdiri dari angkatan LXI 39 orang, angkatan LXII 39 orang, angkatan LXIII 39 orang, dan angkatan LXIV 39 orang sehingga total keseluruhan peserta yaitu 316 orang. Data penilaian peserta diklat berupa evaluasi terhadap coach, pengampu materi, penceramah, mentor, dan penguji. Berdasarkan hasil penilaian peserta diklat, diperoleh data responden per jenis diklat, angkatan, coach, pengampu materi, penceramah, mentor, dan penguji yang tampilkan pada Tabel 1 dan Tabel 2.

Tabel 1 Data Responden Diklat CPNS Golongan II

\begin{tabular}{llcccccc}
\hline \multirow{2}{*}{ No } & \multirow{2}{*}{ Kriteria } & \multicolumn{4}{c}{ Diklat CPNS Golongan II } & \multirow{2}{*}{ Total } \\
\cline { 3 - 6 } & & $\begin{array}{c}\text { Angkatan } \\
\text { VIII }\end{array}$ & $\begin{array}{c}\text { Angkatan } \\
\text { IX }\end{array}$ & $\begin{array}{c}\text { Angkatan } \\
\text { X }\end{array}$ & $\begin{array}{c}\text { Angkatan } \\
\text { XI }\end{array}$ & \\
\hline 1 & Coach & 39 & 40 & 39 & 40 & 158 \\
2 & Pengampu Materi & 809 & 730 & 761 & 719 & 3019 \\
3 & Penceramah & 114 & 117 & 122 & 114 & 467 \\
4 & Mentor & 40 & 40 & 40 & 40 & 160 \\
5 & Penguji & 50 & 51 & 47 & 52 & 200 \\
\hline
\end{tabular}

Tabel 2 Data Responden Diklat CPNS Golongan III

\begin{tabular}{llccccc}
\hline \multirow{2}{*}{ No } & \multirow{2}{*}{ Kriteria } & \multicolumn{5}{c}{ Diklat CPNS Golongan III } \\
\cline { 3 - 6 } & & $\begin{array}{c}\text { Angkatan } \\
\text { LXI }\end{array}$ & $\begin{array}{c}\text { Angkatan } \\
\text { LXII }\end{array}$ & $\begin{array}{c}\text { Angkatan } \\
\text { LXIII }\end{array}$ & $\begin{array}{c}\text { Angkatan } \\
\text { LXIV }\end{array}$ & Total \\
\hline 1 & Coach & 38 & 39 & 39 & 39 & 155 \\
2 & Pengampu Materi & 720 & 711 & 697 & 675 & 2803 \\
3 & Penceramah & 105 & 110 & 114 & 103 & 432 \\
4 & Mentor & 38 & 38 & 38 & 39 & 153 \\
5 & Penguji & 46 & 41 & 44 & 46 & 177 \\
\hline
\end{tabular}


Jurnal Sistem Informasi dan Sistem Komputer, Vol. 5, No. 1, Januari 2020

pISSN : 2581-1614 eISSN : 2715-906X

\subsection{Hasil Pengolahan Data}

Analisis data digunakan metode TOPSIS untuk mencari nilai preferensi komponen yang terdiri dari coach, pengampuh materi, penceramah, mentor, dan penguji. Hasil dari analisis menggunakan metode TOPSIS sebagai berikut.

\subsubsection{Rangking Coach}

Hasil perangkingan setiap coach untuk diklat CPNS golongan II dan golongan III yang dapat dilihat pada Gambar 3 dan Gambar 4.

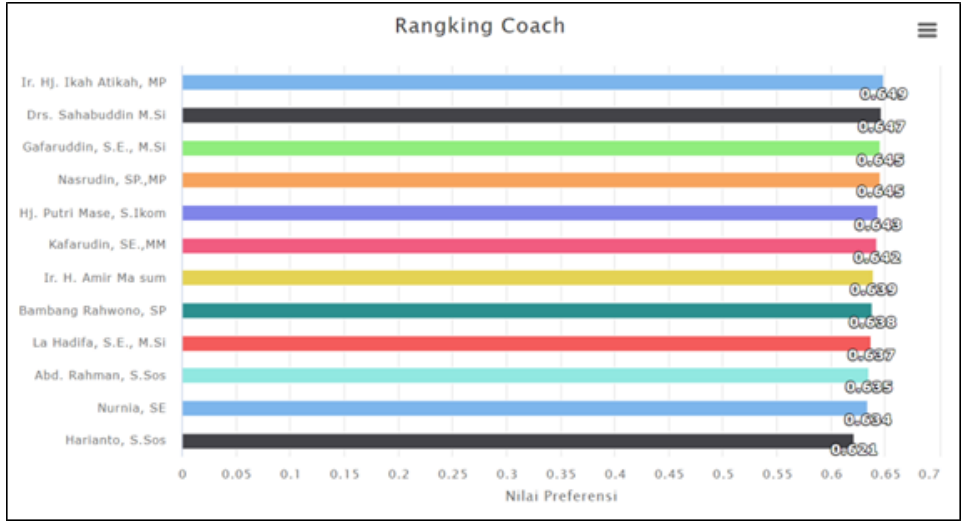

Gambar 3. Rangking Coach Diklat CPNS Golongan II

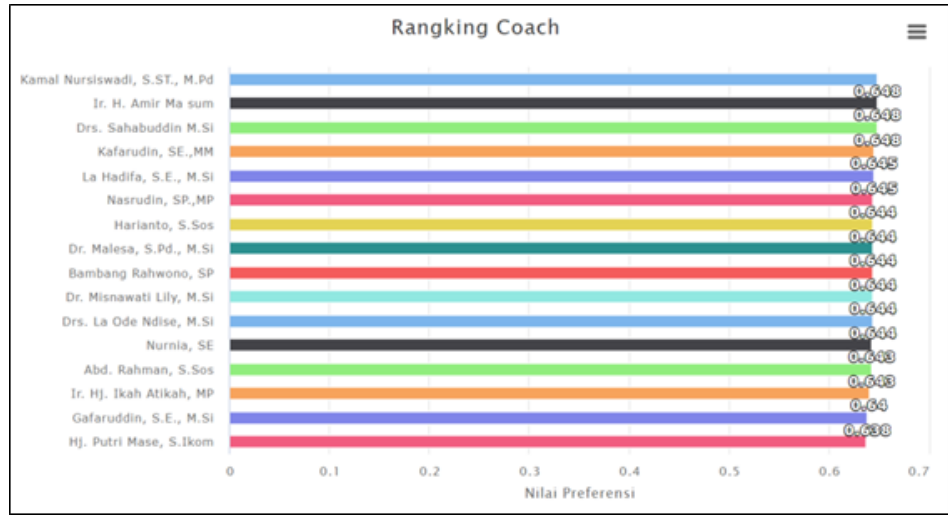

Gambar 4. Rangking Coach Diklat CPNS Golongan III

Hasil perangkingan pada setiap coach untuk diklat CPNS golongan II dan golongan III dapat disimpulkan bahwa bobot setiap coach tidak menunjukkan perbedaan yang signifikan. Adapun coach yang memiliki bobot paling rendah pada pelaksanaan diklat CPNS golongan II yaitu Harianto dengan nilai bobot 0,621, selanjutnya pada pelaksanaan diklat CPNS golongan III yang memiliki bobot paling rendah yaitu Putri Mase dengan nilai bobot 0,638

\subsubsection{Rangking Pengampuh Materi}

hasil perangkingan setiap pengampu materi untuk diklat CPNS golongan II dan golongan III dapat dilihat pada Gambar 5 dan Gambar 6. 
Jurnal Sistem Informasi dan Sistem Komputer, Vol. 5, No. 1, Januari 2020

pISSN : 2581-1614 eISSN : 2715-906X

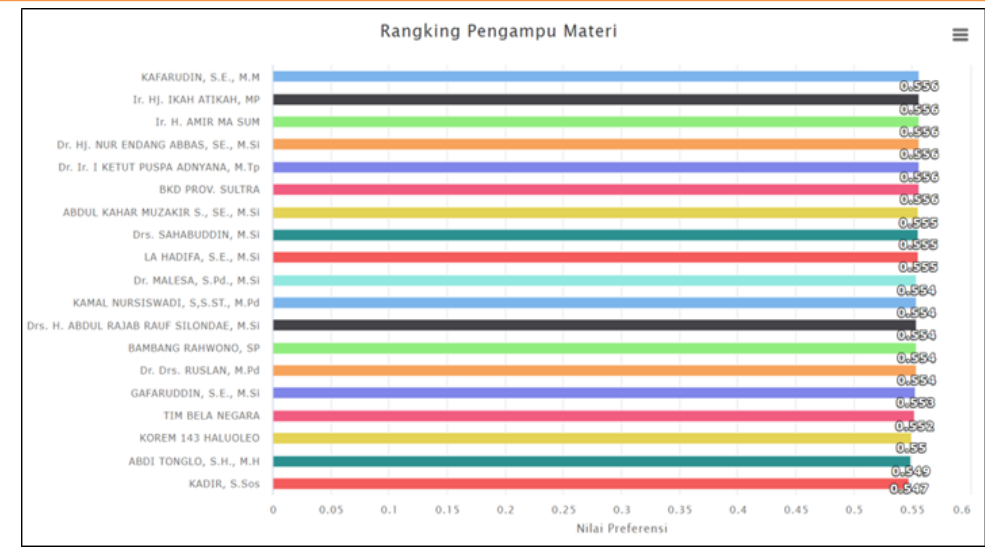

Gambar 5. Rangking Pengampu Materi Diklat CPNS Golongan II

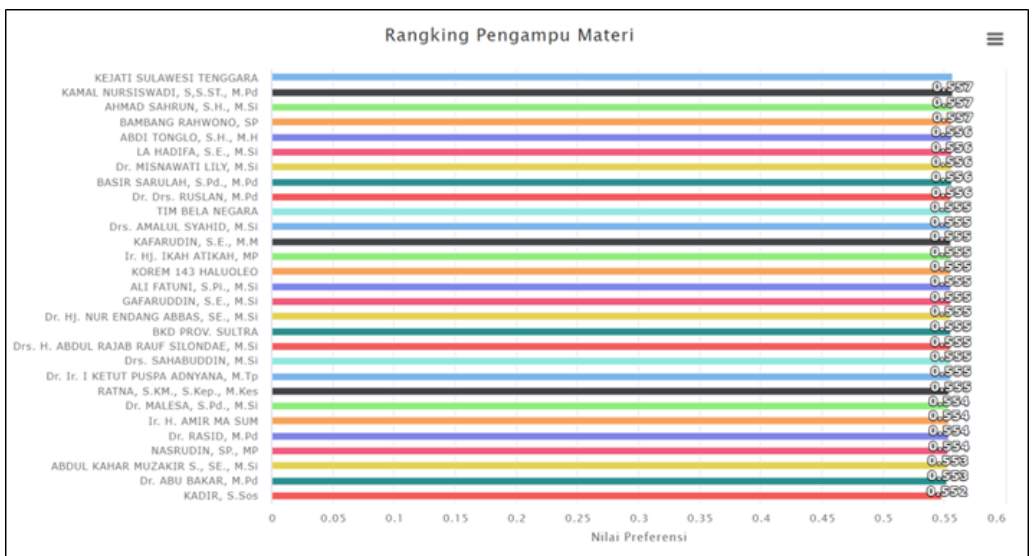

Gambar 6. Rangking Pengampu Materi Diklat CPNS Golongan III

Hasil perangkingan pengampu materi yang ditunjukkan pada Gambar 5 dan Gambar 6 pada pelaksanaan diklat CPNS golongan II menunjukkan pengampu materi memiliki bobot yang paling rendah yaitu Kadir dengan nilai bobot sebesar 0,547 , selanjutnya untuk diklat CPNS golongan III menunjukkan pengampu materi yang memiliki bobot rendah yaitu Kadir dengan nilai bobot sebesar 0,552. Nilai bobot yang diperoleh pengampu materi pada pelaksanaan diklat CPNS golongan III tidak menunjukkan perbedaan yang signifikan.

\subsubsection{Rangking Penceramah}

Hasil perangkingan setiap penceramah pada pelaksanaan diklat CPNS golongan II dan golongan III ditunjukkan pada Gambar 7 dan Gambar 8.

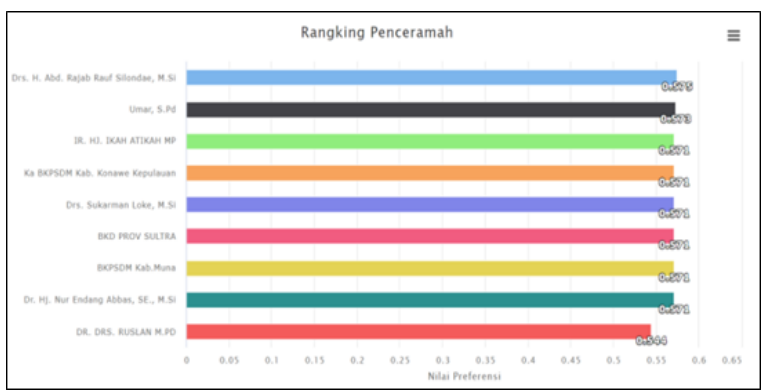

Gambar 7. Rangking Penceramah Diklat CPNS Golongan II 
Jurnal Sistem Informasi dan Sistem Komputer, Vol. 5, No. 1, Januari 2020

pISSN : 2581-1614 eISSN : 2715-906X

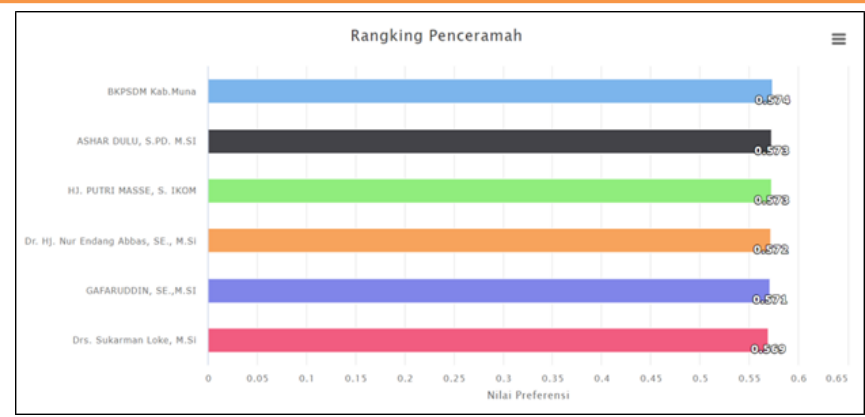

Gambar 8. Rangking Penceramah Diklat CPNS Golongan III

Hasil perangkingan penceramah yang ditunjukkan pada gambar 7 dan Gambar 8 pada pelaksanaan diklat CPNS golongan II menunjukkan penceramah yang memiliki bobot rendah yaitu Ruslan dengan nilai bobot sebesar 0,544 dan perbedaan bobot tersebut sangat signifikan jika dibandingkan penceramah yang lainnya, selanjutnya untuk diklat CPNS golongan III yang memiliki bobot rendah yaitu Sukarman Loke dan tidak menunjukkan perbedaan bobot yang signifikan.

\subsubsection{Rangking Mentor}

Hasil perangkingan setiap mentor pada pelaksanaan diklat CPNS golongan II dan golongan III ditunjukkan pada gambar 9 s.d Gambar 10.

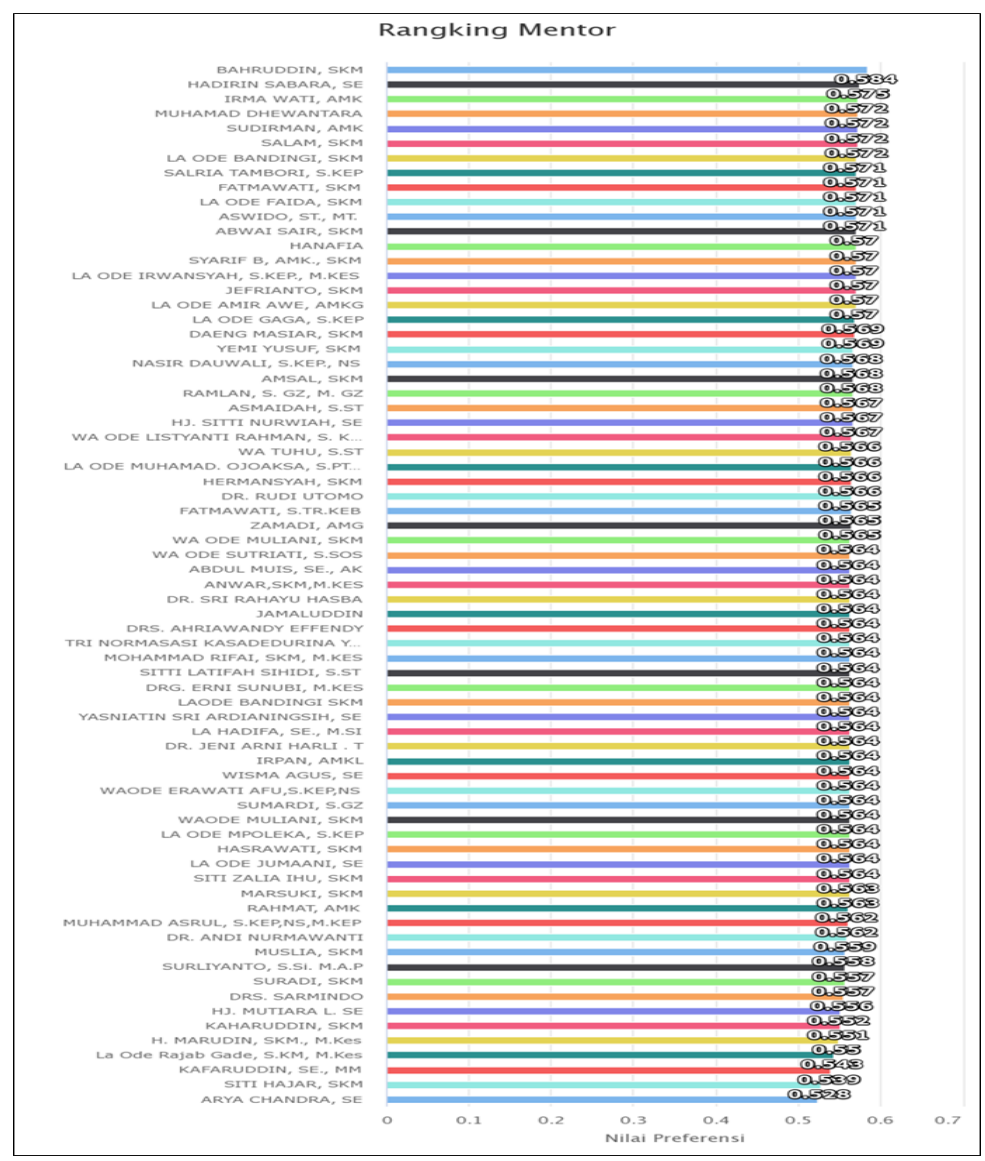

Gambar 9. Rangking Mentor Diklat CPNS Golongan II 
Jurnal Sistem Informasi dan Sistem Komputer, Vol. 5, No. 1, Januari 2020

pISSN : 2581-1614 eISSN : 2715-906X

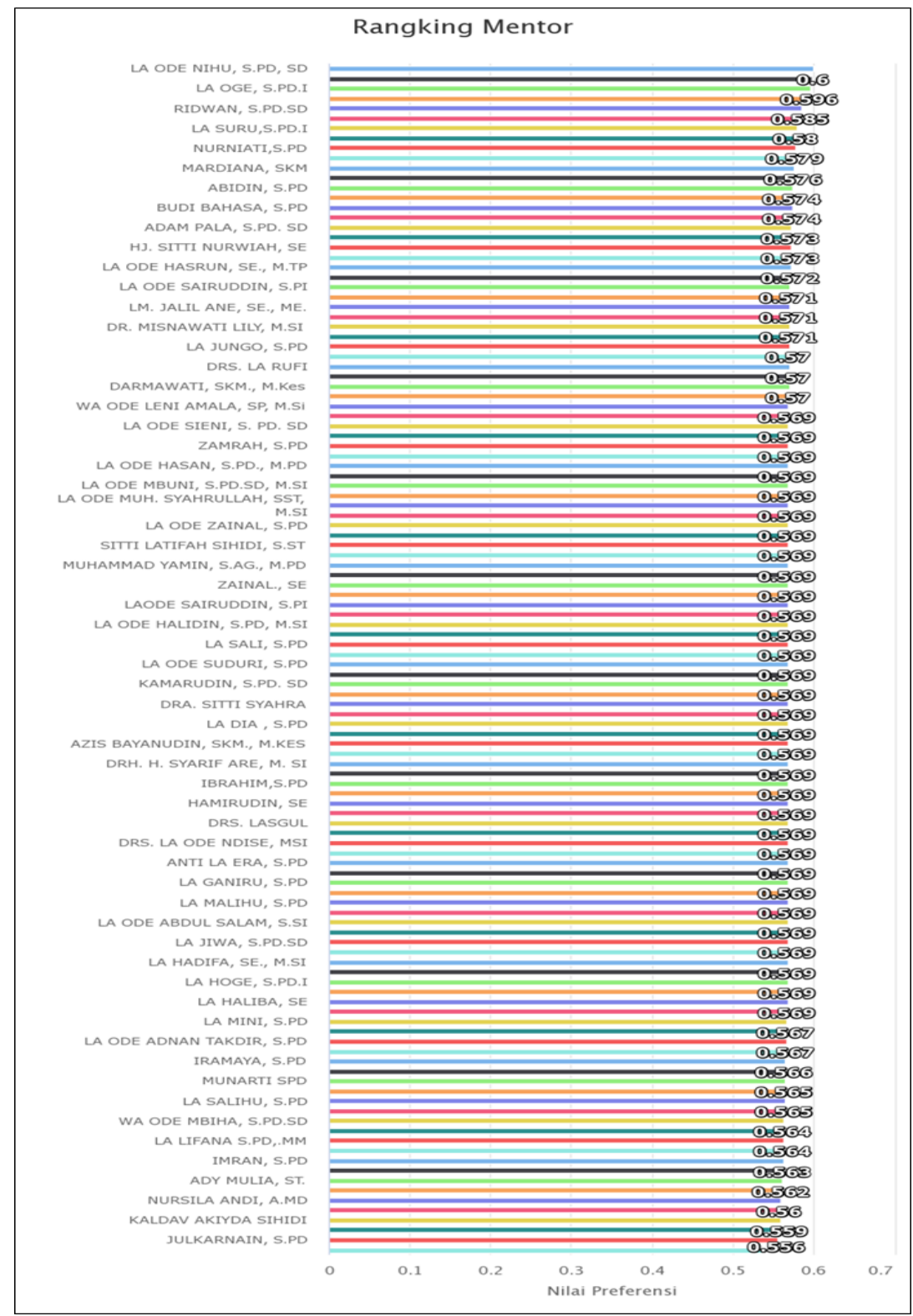

Gambar 10. Rangking Mentor Diklat CPNS Golongan III

Hasil perangkingan mentor yang ditunjukkan pada Gambar 9 pada pelaksanaan diklat CPNS golongan II menunjukkan mentor yang memiliki bobot rendah yaitu Arya Chandra dengan bobot 0,528. Selanjutnya untuk diklat CPNS golongan III yang ditunjukkan pada Gambar 10 mentor yang memiliki bobot rendah yaitu Wa Ima dengan bobot 0,539.

\subsubsection{Rangking Penguji}

Hasil perangkingan setiap penguji pada pelaksanaan diklat CPNS golongan II dan golongan III ditunjukkan pada Gambar 11 dan Gambar 12. 
Jurnal Sistem Informasi dan Sistem Komputer, Vol. 5, No. 1, Januari 2020

pISSN : 2581-1614 eISSN : 2715-906X

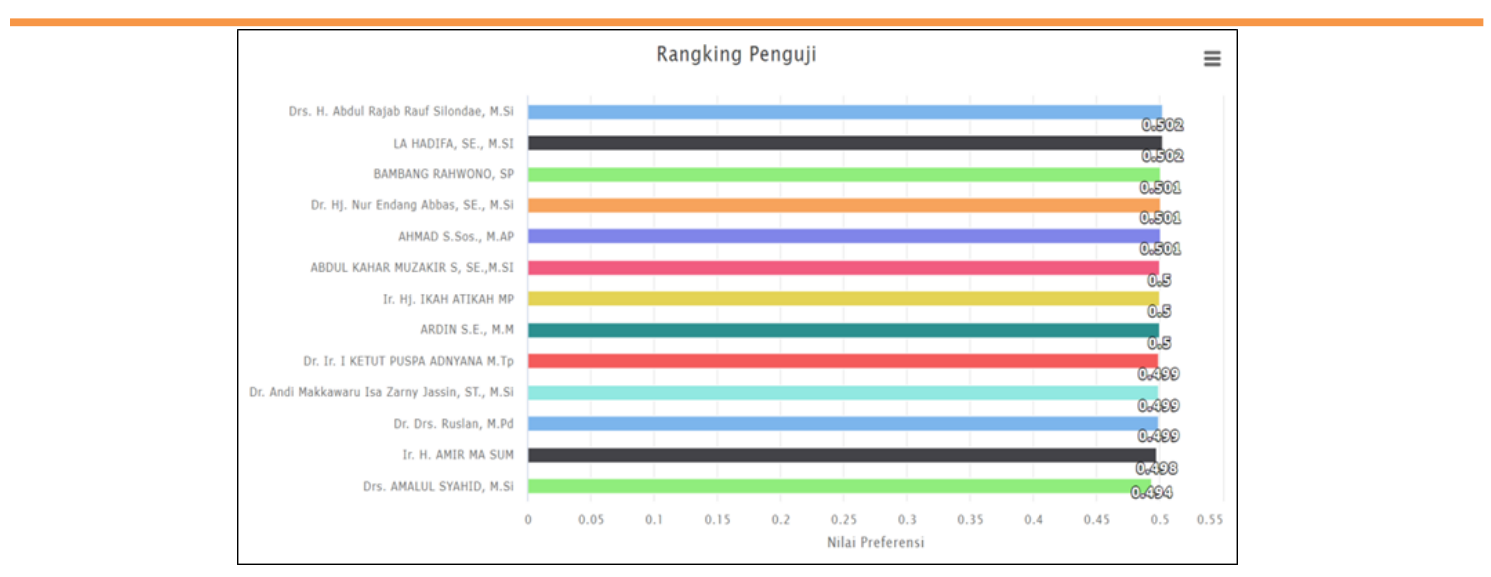

Gambar 11. Rangking Penguji Diklat CPNS Golongan II

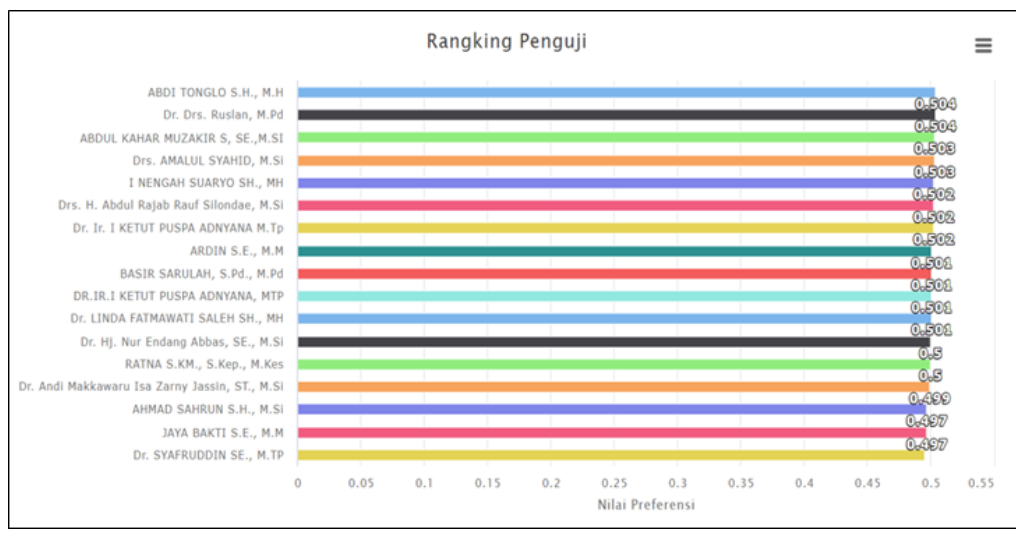

Gambar 12. Rangking Penguji Diklat CPNS Golongan III

Hasil perangkingan penguji yang ditunjukkan pada Gambar 11 pada pelaksanaan diklat CPNS golongan II menunjukkan penguji yang memiliki bobot rendah yaitu Amalul Syahid dengan bobot 0,494. Selanjutnya untuk diklat CPNS golongan III yang ditunjukkan pada Gambar 12 penguji yang memiliki bobot rendah yaitu Syafruddin dengan bobot 0,497. Nilai bobot setiap penguji dari hasil perangkingan menunjukkan perbedaan antara penguji diklat CPNS golongan II dan golongan III dimana nilai bobot pada pelaksanaan diklat CPNS golongan III memiliki nilai bobot lebih tinggi dibandingkan pada pelaksanaan diklat CPNS golongan II.

\subsection{Pengujian dan Akurasi Data}

Pengujian dilakukan untuk mengetahui adanya perubahan tingkat keakuratan hasil analisis dari metode TOPSIS dengan membandingkan hasil keputusan perhitungan secara konvensional dengan hasil keputusan menggunakan sistem yang diusulkan. Hasil keputusan berdasarkan perhitungan secara konvensional tidak menerapkan pendekatan algoritma didalam mengolah data melainkan dilakukan dengan mencari nilai rata-rata setiap variabel. Pengujian dilakukan dengan menggunakan data berdasarkan jenis diklat.

Berdasarkan hasil pengujian tingkat akurasi pada variabel coach, pengampu materi, penceramah, mentor, dan penguji diperoleh tingkat akurasi yang berbeda pada setiap variabel 
Jurnal Sistem Informasi dan Sistem Komputer, Vol. 5, No. 1, Januari 2020

pISSN : 2581-1614 eISSN : 2715-906X

dan berdasarkan jenis diklat. Adapun perbandingan tingkat akurasi setiap variabel ditampilkan dalam bentuk grafik pada Gambar 13.

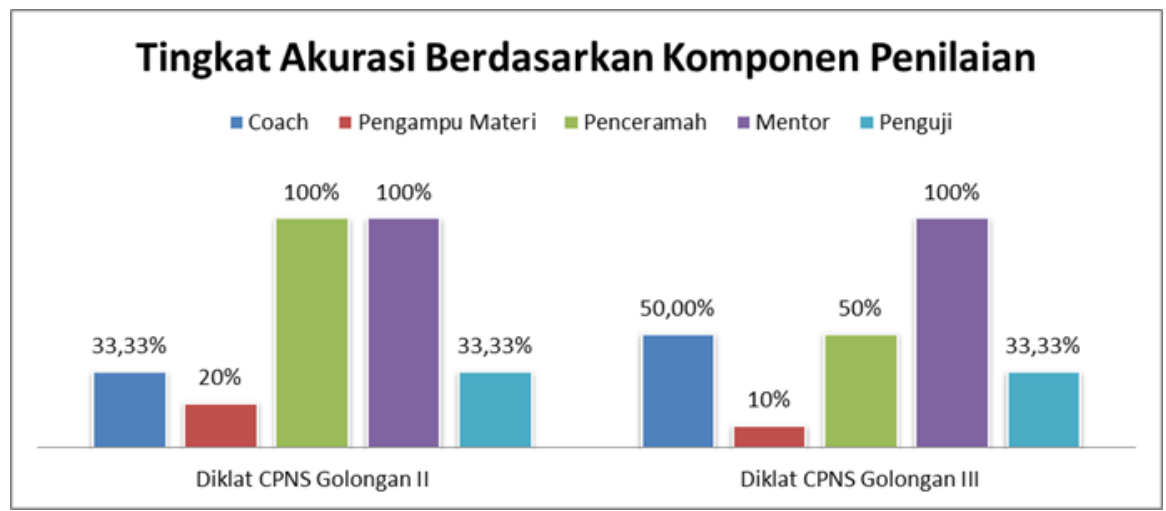

Gambar 13. Perbandingan Tingkat Akurasi Pengujian Rangking Indikator

Keseluruhan pengujian rangking indikator berdasarkan nilai rerata setiap variabel diperoleh tingkat akurasi sebesar 46,62\%. Berdasarkan hasil pengujian, tingkat akurasi yang dihasilkan sangat rendah. Namun, keseluruhan hasil pengujian menunjukkan rekomendasi setiap alternatif keputusan yang perlu diperbaiki memiliki nilai dan rangking yang konsisten atau sesuai dengan rangking secara konvensional.

\section{Kesimpulan dan Saran}

\subsection{Kesimpulan}

Berdasarkan penelitian yang dilakukan terhadap sistem pendukung keputusan penilaian widyaiswara menggunakan pendekatan metode TOPSIS, dapat ditarik kesimpulan sebagai berikut:

1) Uji kriteria menggunakan metode TOPSIS diperoleh urutan kriteria tertinggi adalah penceramah, pengampu materi, penguji, coach mentor.

2) Hasil perangkingan alternatif menggunakan metode TOPSIS diperoleh alternatif keputusan yang perlu ditingkatkan berdasarkan kriteria coach yaitu kemampuan membimbing, penggunaan metode dan media pembimbingan, berdasarkan kriteria pengampu materi yaitu penggunaan metode dan sarana pelatihan, berdasarkan kriteria penceramah yaitu cara penyajian materi, dan penguasaan materi, berdasarkan kriteria mentor yaitu penggunaan metode dan media pembimbingan, berdasarkan kriteria penguji yaitu pemberian motivasi dan inspirasi kepada peserta.

3) Hasil pengujian akurasi metode TOPSIS dalam penelitian ini sangat rendah. Namun, berdasarkan alternatif keputusan yang direkomendasikan TOPSIS memiliki kesesuaian dengan alternatif yang direkomendasikan secara konvensional.

4) Sistem pendukung keputusan dengan metode TOPSIS dapat digunakan sebagai alternatif pengambilan keputusan pada penilaian kualitas Widyaiswara. 
Jurnal Sistem Informasi dan Sistem Komputer, Vol. 5, No. 1, Januari 2020

pISSN : 2581-1614 eISSN : 2715-906X

\subsection{Saran}

Berdasarkan kesimpulan yang telah diuraikan. Maka, peneliti memberikan saran yaitu:

1) Perlu adanya penelitian lebih lanjut untuk mengetahui seberapa besar pengaruh kualitas widyaiswara terhadap keberhasilan peserta diklat.

2) Penggunaan metode TOPSIS pada penelitian selanjutnya, sebaiknya nilai preferensi tidak dibulatkan agar tidak mempengaruhi tingkat akurasi.

3) Sebaiknya peneliti membandingan metode TOPSIS dengan metode MADM seperti Axiomatic Desain dan ELECTRE.

\section{Daftar Pustaka}

[1] Peraturan Lembaga Administrasi Negara Republik Indonesia Nomor 12 Tahun 2018 Tentang Pelatihan Dasar Calon Pegawai Negeri Sipil.

[2] Muhamad Meky Frindo. 2018. "Sistem Penunjang Keputusan Dalam Evaluasi Kinerja Karyawan Menggunakan Metode SAW Pada PT. Sierad Produce". Jurnal Informatika Universitas Pamulang Vol. 3, No. 1, pp 13-19.

[3] Achmad, Yusni, Abdul Najib. 2018. "Perbandingan Metode SAW dan TOPSIS Pada Penerimaan Siswa Praktek Kerja Lapangan". Prosiding Seminar Nasional Ilmu Komputer dan Teknologi Informasi Vol. 3, No. 1, pp 71-77.

[4] Wina Yusnaeni, Rahayu Ningsih. 2019. "Analisa Perbandingan Metode TOPSIS, SAW, dan WP Melalui Uji Sensitifitas Supplier Terbaik". Jurnal Informatika Vol. 6, No. 1, pp 9-17.

[5] Ni Kadek Sukerti. 2015. "Penerapan Fuzzy TOPSIS Untuk Seleksi Penerima Bantuan Kemiskinan". Jurnal Informatika Vol. 15, No. 2, pp 127-140.

[6] Ditdit Nugeraha Utama. 2017. "Sistem Penunjang Keputusan: Filosofi, Teori dan Implementasi". Garudhawaca, Yogyakarta.

[7] Turban. dkk., 2005, "Decision Support System and Intelligent System (Sistem Pendukung Keputusan dan Sistem Cerdas)", Andi, Yogyakarta.

[8] Kusrini. 2007. "Konsep dan Aplikasi Sistem Pendukung Keputusan. Yogyakarta: Andi.

[9] Amelia Nur Fitriana, Harliana, Handaru. 2015. "Sistem Pendukung Keputusan Untuk Menentukan Prestasi Akademik Siswa dengan Metode TOPSIS". Citec Journal Vol. 2, No. 2, pp 153-164.

[10] Kusumadewi, S., Hartati, S., Harjoko, A., Wardoyo, R. 2006. "Fuzzy Multi Atribut Decision Making (Fuzzy MADM)", Graha Ilmu, Yogyakarta.

[11] Peraturan Pemerintah Republik Indonesia Nomor 101 Tahun 2000 Tentang Diklat Pegawai Negeri Sipil.

[12] Notoatmodjo, S. 2003. "Pengembangan Sumber Daya Manusia”. Jakarta: Rineka Cipta.

[13] Subagyo, P. 1995. "Manajemen kepegawaian". Jakarta: Ghalia Indonesia.

[14] Peraturan Menteri Pendayagunaan Aparatur Negara dan Reformasi Birokrasi Republik Indonesia Nomor 22 Tahun 2014 Tentang Jabatan Fungsional Widyaiswara dan Angka Kreditnya.

[15] Groundlund, Norman E. Dan Robert L. Linn, 200. "Measurement and Evaluation in Teaching". New York: McMilan Publishing Co.

[16] Djaali dan Puji Mulyono, 2000. "Pengukuran dalam Bidang Pendidikan". Jakarta: PPs UNJ.

[17] Blaine, Worten B., James R Sanders dan Jodi L. Fitzpatrick. 2004. "Program Evaluation Alternatives Approach and Practical Guidelines". Boston: Pearson Education Inc.

[18] Kaufman, R., \& Thomas, S. 1980. "Evaluation without Fear". New York: New. Viewpoints. 